\title{
Sistem Informasi Pelayanan Administasi Kependudukan Desa (M-Desa) Dengan Metode User Centered Design
}

\author{
Yustina Meisella Kristania \\ Universitas Nusa Mandiri \\ Email: yustina.yms@nusamandiri.ac.id
}

\begin{abstract}
Abstrak
Dewasa ini ketergantungan manusia akan akses informasi semakin bertambah dengan ditandainya penggunaan internet yang makin tersebar. Desa sebagai bagian terkecil dari sistem pemerintahan administratif di Indonesia, dituntut dapat mengikuti perkembangan teknologi dan terus meningkatkan kemampuannya mengelola data administrasi kependudukan desa. Saat ini masih banyak desa dalam sistem pelayanannya masih melayani secara konvensional. Pelayanan administasi kependudukan seperti pencatatan data penduduk desa dan pembuatan surat permohonan akan lebih efektif dan efisien dengan memaksimalkan penggunaan teknologi informasi, yaitu melalui pemanfaatan Sistem Informasi Pelayanan Administasi Kependudukan Desa (M-DESA) menggunakan metode User Centered Design (UCD). Metode UCD berfokus kepada pengembangan sistem berdasarkan tujuan, sifat, konteks dan lingkungan melalui pengalaman pengguna. Sedangkan teknik pengumpulan data menggunakan observasi, wawancara dan studi pustaka. Dengan adanya Sistem Informasi Pelayanan Administasi Kependudukan Desa (M-DESA) dapat mempermudah masyarakat yang akan mengajukan pelayanan karena dapat diakses dimana saja melalui jaringan internet seperti pelayanan permohonan pendaftaran E-KTP, KK, AKTE dan surat-surat lainnya, Sehingga ada keterbukaan dan kemudahan dalam pelayanan antara pengurus desa dengan warganya.
\end{abstract}

Kata kunci: Desa, administrasi, sistem informasi, metode User Centered Design

\begin{abstract}
Today, human dependence on access to information is increasing with the mark of increasingly widespread use of the internet. The village, as the smallest part of the administrative government system in Indonesia, is required to be able to follow technological developments and continue to improve its ability to manage village population administrative data. Currently there are still many villages in their service system that still serve conventionally. Population administrative services such as recording village population data and making application letters will be more effective and efficient by maximizing the use of information technology, namely through the use of the Village Population Administration Service Information System (M-DESA) using the User Centered Design (UCD) method. The UCD method focuses on developing systems based on objectives, nature, context and environment through user experience. While the data collection techniques used observation, interviews and literature study. With the Village Population Administration Service Information System (M-DESA) it can make it easier for people who will apply for services because it can be accessed anywhere via the internet network such as service for E-KTP registration, KK, AKTE and other letters, so that there is openness and convenience in services between village administrators and residents.
\end{abstract}

Keywords: Village, administration, information systems, User Centered Design methods 
Indonesian Journal on Software Engineering (IJSE)

Vol. 7, No. 1, Juni 2021, hlm. 1-9

\section{PENDAHULUAN}

Saat ini teknologi telah memasuki hampir sebagian besar sektor kehidupan, sehingga hal tersebut telah membawa kemudahan bagi manusia, salah satunya adalah komputer. Ketergantungan manusia akan akses informasi semakin bertambah seiring dengan ditandainya penggunaan internet yang makin tersebar. Baik itu badan usaha ataupun instansi pemerintah dapat melakukan mengelola data dan informasi dengan bantuan komputer. Desa sebagai kesatuan masyarakat hukum yang memiliki kewenangan untuk mengatur dan mengurus kepentingan masyarakat setempat yang diakui dan dihormati dalam sistem Pemerintahan Negara Kesatuan Republik Indonesia (Indonesia, 2004) dituntut untuk dapat mengikuti perkembangan teknologi dan terus meningkatkan kemampuannya didalam mengelola data administrasi kependudukan desa. Saat ini masih banyak desa dalam sistem pelayanan administrasi kependudukan desa masih melayani masyarakat secara konvensional, seperti pencatatan data penduduk desa dalam buku pendaftaran, pembuatan surat-surat permohonan yang masih manual dan kemampuan IT yang masih terbatas. Hal tersebut berimbas kepada perangkat desa maupun penduduk desa, dimana sering terjadi human error, serta pemborosan waktu dan biaya. Oleh karena itu dibutuhkan suatu sistem untuk mengatasi permasalahan-permasalahan yang ada. Dibutuhkan suatu sistem pelayanan terpadu pada kelurahan yang dapat membantu mengolah data supaya lebih cepat dan akurat, sehingga mempercepat penyampaian informasi yang dibutuhkan dan menjadi sarana pendukung aktivitas kependudukan yang praktis dalam penyajian data kependudukan (Muhammad \& Bahar, 2016)

Pelayanan administasi kepada masyarakat akan lebih efektif dan efisien apabila dibantu dengan memaksimalkan penggunaan teknologi informasi, yaitu melalui Sistem Informasi Pelayanan Administrasi Kependudukan Desa (M-DESA) masyarakat dengan menggunakan metode User Centered Design (UCD). Metode UCD berfokus kepada proses pengembangan sistem dari tujuan, sifat, konteks dan lingkungan yang didasarkan kepada pengalaman pengguna dengan proses evaluasi dalam permulaan sampai dengan implementasi. Dalam pengolahan permohonan surat yang berkaitan dengan administrasi pelayanan kependudukan masih kurang akurat dan efisien, sebagai akibatnya dalam menyelesaikan kegiatan pelayanan terasa kurang efektif dan lama. Metode pengembangan perangkat lunak yang digunakan adalah model waterfall mengenai analisis kebutuhan warga Desa dan petugas pelayanan, yang kemudian diteruskan desain, pembuatan kode program, pengujian, dan pendukung atau pemeliharaan dengan dibuatnya website. Dengan adanya Sistem Informasi Pelayanan Administrasi Kependudukan Desa (MDESA) sebagai sarana pelayanan jasa untuk masyarakat, dapat mempermudah pelayanan permohonan surat yang berkaitan dengan administrasi kependudukan, mulai dari mendapatkan informasi tentang syarat pendaftaran E-KTP, KK, AKTE dan surat-surat lainnya, hingga proses pendaftarannya bisa diakses melalui jaringan internet

\section{METODE PENELITIAN}

Penulis menggunakan metode deskriptif kualitatif dalam merancang Sistem Informasi Pelayanan Administrasi Kependudukan Desa, yaitu menurut (Ariansyah \& Josi, 2017) metode deskriptif kualitatif mempunyai pengertian informasi berupa kalimat verbal bukan berbentuk simbol angka dan bilangan.Tahapan dalam mengumpulkan data yaitu melalui metode wawancara (Interview) dan Observasi (Observation).

Wawancara dilakukan dengan salah satu pihak perangkat Desa mengenai Pelayanan Administrasi Kependudukan yang telah berjalan selama ini. Kemudian untuk Observasi dilakukan dengan mengamati secara langsung dokumen-dokumen yang digunakan seperti syarat pendaftaran E-KTP, KK, AKTE dan surat-surat lainnya. Dari hasil wawancara dan observasi ini diharapkan mendapat gambaran rancangan sistem informasi seperti apa yang dapat membantu pihak Desa dan warga dalam memproses data Pelayanan Administrasi Kependudukan.

a. Objek Penelitian

Berdasarkan dengan informasi yang diperlukan dalam penelitian ini, penulis menetapka objek penelitian yaitu Sistem Informasi Pelayanan Administasi Kependudukan Warga Desa yang ada di sekitar kabupaten Banyumas dan seluruh pengguna/user yang terlibat dengan Sistem Informasi tersebut.

b. Sampel Penelitian

Sampel yang digunakan dalam penelitian ini diambil secara acak (random sampling) dari responden yang akan menggunakan Sistem Informasi Pelayanan Administasi Kependudukan Desa. Peneliti mengambil 15 sampel. 


\section{HASIL DAN PEMBAHASAN}

\section{a. Analisa Sistem Berjalan}

Warga datang ke kantor kepala desa dengan membawa surat pengantar dari RT dan RW kebagian pelayanan. Kemudian Bagian pelayanan menerima surat pengantar dan memberikan informasi tentang persyaratan yang harus dipenuhi untuk membuat Surat (E-KTP, KK, AKTE, dII). Jika persyaratan sudah lengkap maka penduduk langsung diberi formulir untuk diisi. Bagian pelayanan menerima formulir tersebut dan mengecek ulang kelengkapan persyaratan pembuatan Surat (E-KTP, KK, AKTE, dII), dan jika dinyatakan telah memenuhi persyaratan, maka kemudian langkah selanjutkan bagian pelayanan membuatkan surat pengantar pembuatannya untuk dibawa ke kecamatan. Surat yang sudah dibuat akan diserahkan kepada kepala desa untuk ditandatangani dan di cap resmi oleh kelurahan. Setelah itu surat akan diberikan kepada warga. Setiap surat yang dikeluarkan oleh kelurahan akan dicatat di buku registrasi dan dibuat laporannya.

\section{b. Analisa Kebutuhan Sistem}

1) Hak ases

Sistem harus dapat melakukan penyaringan pengguna dengan menggunakan akses level pengguna sejauh hak akses yang diberikan kepada pengguna tersebut, antara lain : Hak Akses Admin (petugas) dan hak akses Kepala desa

2) Pengolahan Data

Dalam sistem ini, terdapat pengolahan data yang akan dikelola, diantaranya: Data admin, Data surat masuk, Data surat keluar, Data arsip dan Data Bagian.

3) Keamanan

Dalam pembatasan hak akses, terdapat halaman yang tidak bisa diakses oleh pengguna tertentu. Sehingga pengguna yang tidak memiliki hak akses tidak dapat mengakses halaman tersebut. Untuk mengakses halaman tersebut, pengguna harus melakukan otentifikasi melalui halaman login dengan menggunakan nik dan password. Selain itu password harus dienkripsi menggunakan fungsi md5 di dalam database.

c. Tahapan Ucer Centered Learning(UCD)

1) Plan the human centered process

Peneliti berdiskusi dengan pihak-pihak yang terkait dengan perancangan sistem ini yaitu petugas Balai Desa dan warga, mengenai perencanaan perancangan Sistem Informasi Pelayanan Administasi Kependudukan Desa (M-DESA) yang berpusat pada pengguna yaitu warga masyarakat desa.

2) Specify the context of use

3) Sistem Informasi Pelayanan Administasi Kependudukan Desa (M-DESA) merupakan sistem yang menyediakan form pendaftaran untuk dapat mengakses layanan masyarakat yaitu mengubah maupun mendaftar berbagai dokumen seperti E-KTP, KK, AKTE Kelahiran, Surat Pengantar Nikah, surat kehilangan, mengurus kepindahan dan surat kematian. Form pendaftaran ini berfungsi sebagai pengganti surat pengantar dari RT/RW. Serta disediakan pula informasi seputar Info Desa mengenai struktur pemerintahan desa, seperti Kepala Desa, Sekretaris Desa, Kepala Seksi Pelayanan, Kesejahteraan, Pemerintahan, Kepala Urusan Keuangan, Umum, Perencanaan, dan Kepala disetiap Dusun desa. Lalu informasi Kegiatan Desa yang berkaitan dengan jadwal kegiatan desa, berupa posyandu, karang taruna, musyawarah rutin, dan kegiatan lainnya.

4) Specify user and organisational requirement

Peneliti mengidentifikasi kebutuhan warga khususnya masyarakat desa dan petugas balai desa untuk keperluan sistem pengolahan data layanan administrasi masyarakat yang akan dirancang yakni kebutuhan data warga desa dan data petugas balai desa lalu berikutnya adalah kebutuhan fungsional yaitu sistem yang dibangun dapat mengelola data master, data transaksi pendaftaran administrasi masyarakat dan dapat mencetak laporan yang diperlukan.

5) Product design solutions

Berikutnya peneliti melakukan perancangan sistem yang dimulai dengan pengembangan perangkat lunak dengan menggunakan metode prototyping. Langkah-langkah Prototyping yaitu diawali dengan pengumpulan kebutuhan, melibatkan pengembang dan pengguna sistem untuk menentukan tujuan, fungsi dan kebutuhan operasional system (Ogedebe \& Jacob, 2012). Kegiatan tersebut antara lain 
Indonesian Journal on Software Engineering (IJSE)

Vol. 7, No. 1, Juni 2021, hlm. 1-9

p-ISSN: 2461-0690

Akreditasi KEMENRISTEKDIKTI, No. 85/M/KPT/2020

e-ISSN: 2714-9935

sebagai berikut : pengumpulan kebutuhan awal sistem (ide dan gagasan), desain berupa spesifikasi sistem, membangun prototipe, evaluasi dan perbaikan.

6) Evaluate design againts user requiremen

Didalam tahapan evalulasi pengguna ini, penulis menggunakan kuisioner dengan pengambilan sampel secara acak (random sampling) dari responden yang akan menggunakan Sistem Informasi Pelayanan Administasi Kependudukan Desa (M-DESA), peneliti mengambil 15 sampel.

\section{d. Use Case}

Sistem mempunyai tiga pengguna yang terdiri dari admin, kepala desa dan warga. Masing-masing mempunyai hak akses yang berbeda-beda. Akun kepala desa dibuat oleh admin melalui menu pendaftaran data kepala desa, akun warga dapat dibuat dengan melakukan pendaftaran akun pada menu pendaftaran di bagian front-end. Untuk pembuatan surat, Masyarakat dapat memasukan NIK ke sistem. Setelah data diisi, surat dapat diprint. Kemudian surat di bawa ke petugas untuk di uruskan pengesahaannya oleh Kepala Desa.

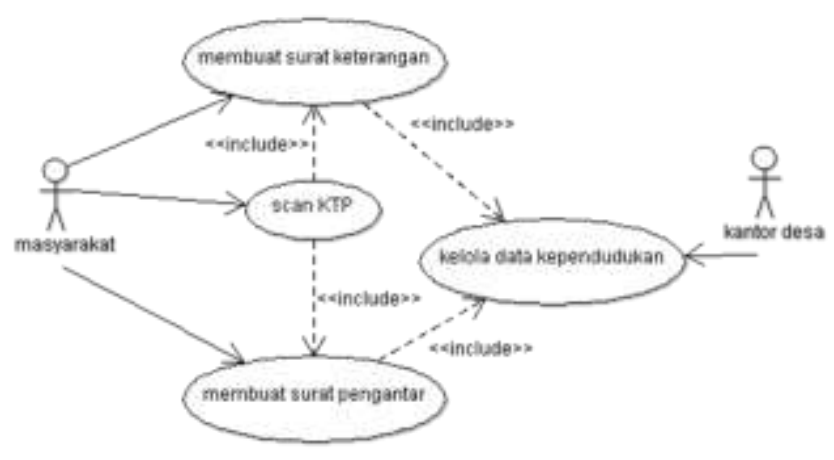

Gambar 2. Use Case

\section{e. Entity Relationship Diagram (ERD)}

Pada sistem ini terdapat lima jenis surat yang dikelola, yaitu surat domisili, surat permohonan Kartu Keluarga (KK), surat permohonan KTP, surat pindah dan surat permohonan SKCK. Setiap pengelolaan surat dihubungkan dengan data warga.

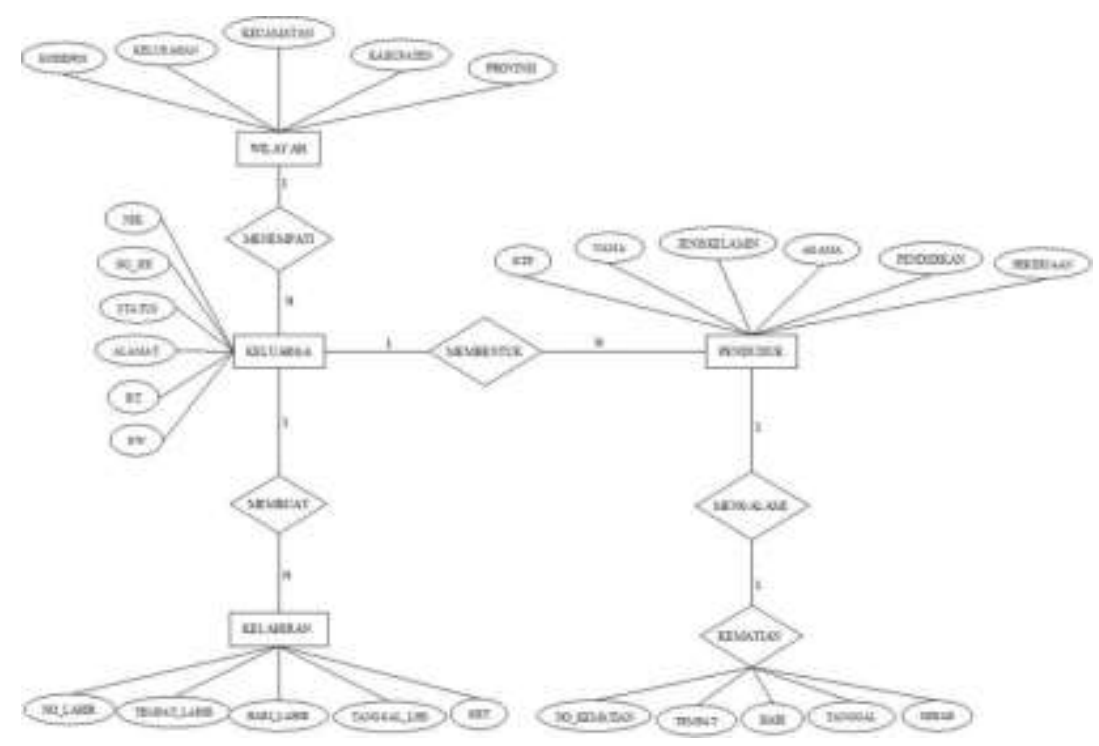

Gambar 3. Entity Relationship Diagram (ERD) 
Indonesian Journal on Software Engineering (IJSE)

Vol. 7, No. 1, Juni 2021, hlm. 1-9

f. Logical Record Structure (LRS)

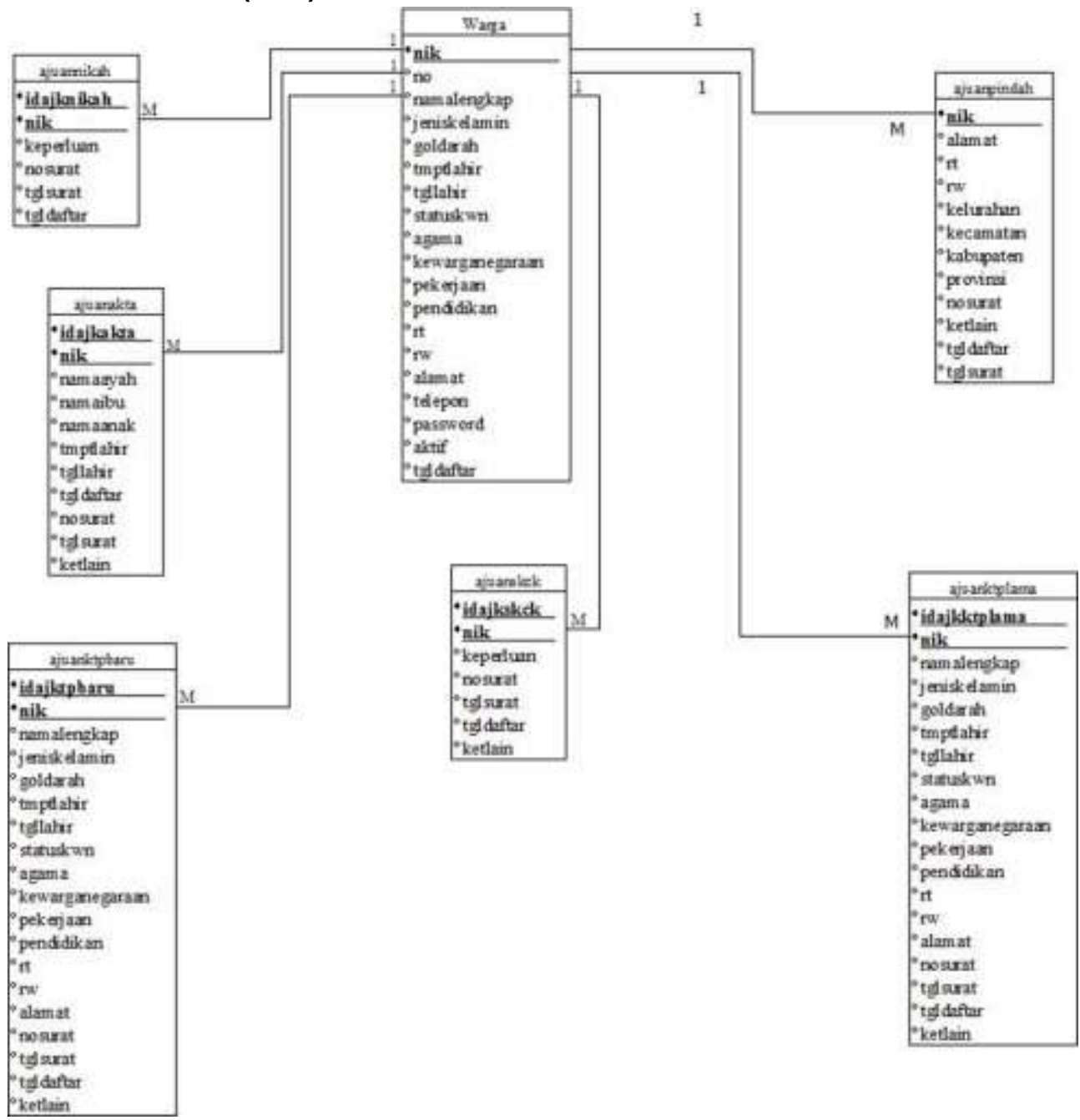

Gambar 4. Logical Record Structure (LRS)

\section{g. User Interface}

1) Halaman Pengguna

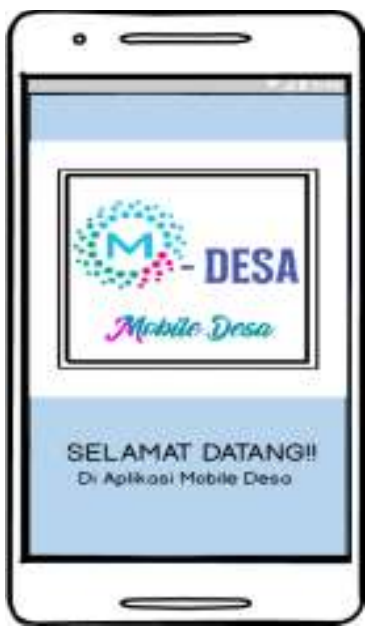

Gambar 5. Halaman Pengguna

Tampilan awal ketika pengguna membuka sistem M-DESA, terdapat logo dan ucapan selamat datang. 
Indonesian Journal on Software Engineering (IJSE)

Vol. 7, No. 1, Juni 2021, hlm. 1-9

2) Halaman Pendaftaran

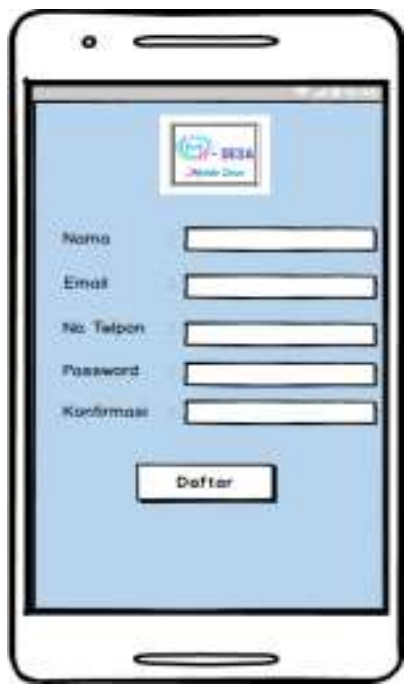

Gambar 6. Halaman Pendaftaran

Pengguna di wajibkan untuk mengisi setiap form pendaftaran yang terdapat dalam sistem untuk kepentingan dalam proses data diri yang di perlukan untuk mengetahui data diri penduduk sebagai pengguna sistem M-Desa tersebut, setelah semua form data diri telah diisikan dengan benar lalu klik Daftar untuk melanjutkan proses selanjutnya

3) Halaman Login

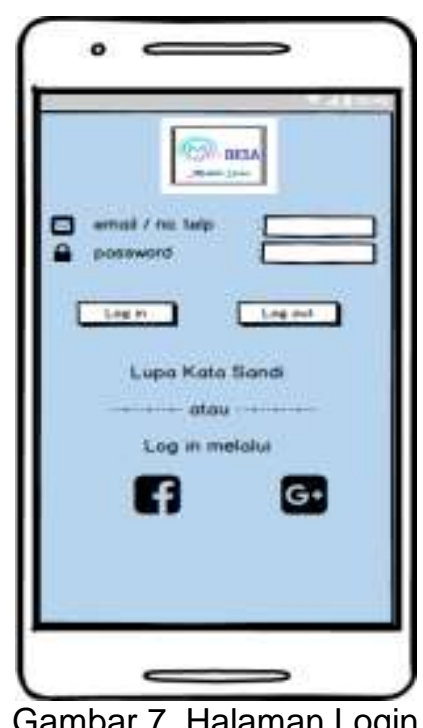

Pengguna masuk dengan mengisi form email/ no telepon dan password yang telah terdaftar .Lalu mengeklik tombol login, apabila pengguna lupa kata sandinya pengguna dapat mengeklik tulisan lupa kata sandi atau bisa saja login melalui media sosial seperti facebook, akun google plus. 
Indonesian Journal on Software Engineering (IJSE)

Vol. 7, No. 1, Juni 2021, hlm. 1-9

4) Halaman Surat Menyurat

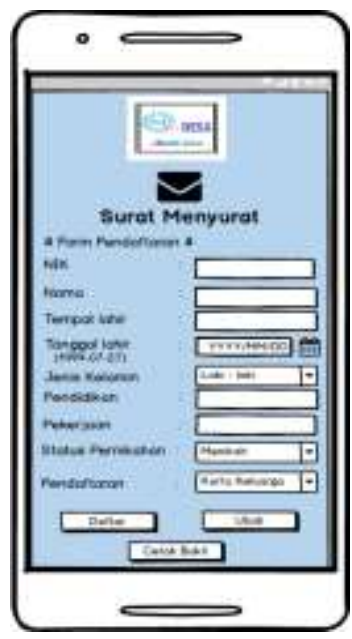

Gambar 8. Halaman Surat Menyurat

Didalam menu "Surat Menyurat", terdapat form pendaftaran pengguna untuk mengajukan pelayanan dokumen yang bisa diakses. Form pendaftaran ini berfungsi sebagai pengganti surat pengantar dari RT/RW. Lalu pengguna memilih jenis dokumen yang akan diurus seperti E-KTP, KK, AKTE Kelahiran, Surat Pengantar Nikah, surat kehilangan, mengurus kepindahan, surat kematian, dan ada pilihan lainnya jika dokumen yang akan diurus tidak terdapat dipilihan utama, lalu pengguna mengetikan dokumen apa yang akan diurus. Disini terdapat opsi daftar untuk mendaftar dokumen baru, dan opsi ubah untuk mengubah dokumen yang telah terdaftar. Jika sudah selesai silahkan klik cetak bukti. Cetak bukti ditunjukan ketika datang ke kantor balai desa.

5) Halaman Kegiatan Desa

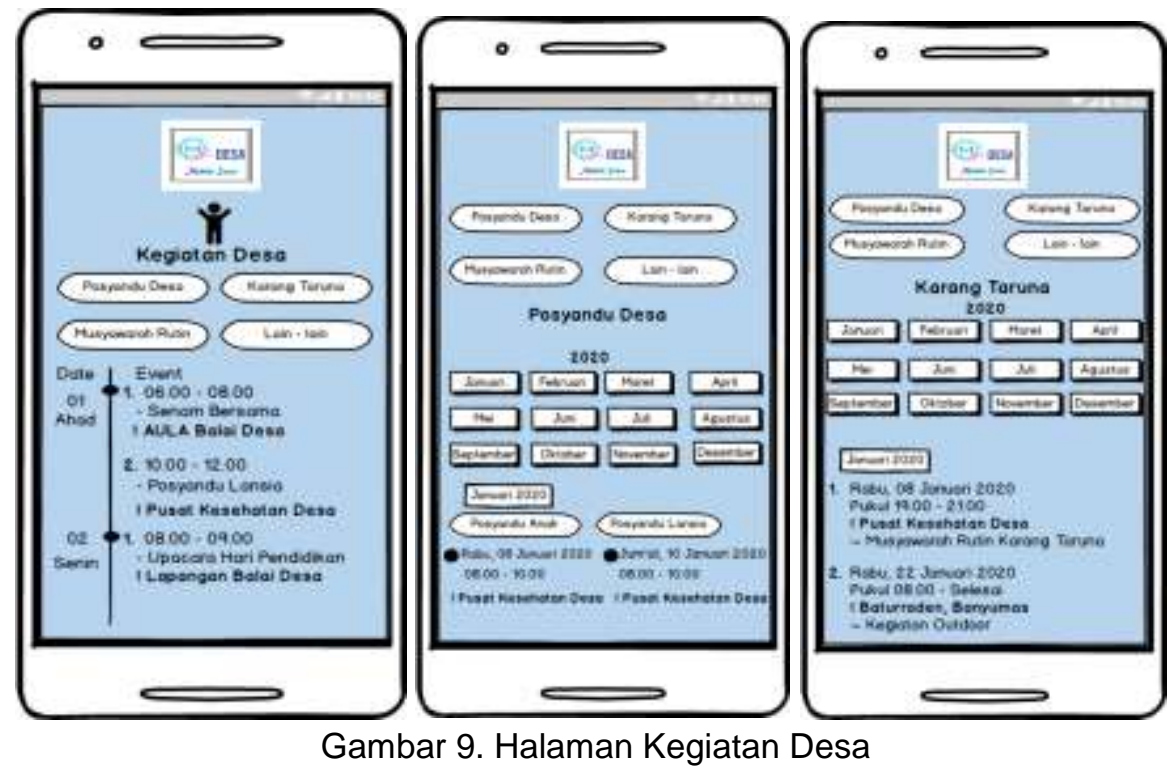

Pada Halaman Kegiatan Desa terdapat informasi mengenai jadwal kegiatan desa, berupa posyandu desa, karang taruna, musyawarah rutin, dan kegiatan lainnya. Disini ada kalender yang menampilkan bulan, tanggal, hari serta seluruh kegiatan apa saja yang terdapat di bulan tersebut. Diketerangan kegiatan pun lengkap dengan jenis kegiatan yang dilaksanakan, waktu, dan tempat. 
Indonesian Journal on Software Engineering (IJSE)

Vol. 7, No. 1, Juni 2021, hlm. 1-9

p-ISSN: 2461-0690

Akreditasi KEMENRISTEKDIKTI, No. 85/M/KPT/2020

e-ISSN: 2714-9935

\section{h. Uji Rancangan Antarmuka}

Pada langkah ini pengguna (warga dan pihak perangkat desa) memberikan tanggapan terkait sistem yang dirancang melalui kuesioner yang di sediakan.

Tabel 1. Rekap kuisioner uji rancangan antarmuka

\begin{tabular}{rlrrrrr}
\hline No & \multicolumn{1}{c}{ Pertanyaan } & \multicolumn{5}{c}{ Nilai } \\
\hline & Apakah informasi yang disediakan oleh sistem pelayananan ini akan mudah & & & & & \\
1 & dimengerti? & 1 & 2 & 3 & 4 & 5 \\
2 & Apakah sistem pelayanan ini akan sesuai dengan kebutuhan? & 0 & 0 & 1 & 4 & 10 \\
3 & Apakah sistem pelayanan ini akan dapat dengan mudah dipelajari? & 0 & 0 & 0 & 9 & 6 \\
4 & Apakah tampilan menu dalam sistem pelayanan akan mudah untuk dikenali? & 0 & 0 & 5 & 5 & 5 \\
5 & Apakah tampilan menu dalam sistem pelayanan akan mudah untuk dikenali? & 0 & 0 & 4 & 6 & 5 \\
& Apakah tampilan media pelayanan administrasi warga desa pada sistem ini \\
6 & menarik? & 0 & 1 & 1 & 4 & 9 \\
7 & Apakah simbol-simbol gambar mudah dipahami? & 0 & 0 & 1 & 7 & 7 \\
& Apakah sistem ini dapat dijadikan sebagai media bantu pelayanan & & & & & \\
8 & administrasi masyarakat? & 0 & 0 & 3 & 6 & 7 \\
\hline
\end{tabular}

Tabel 2. Hasil kuisioner uji rancangan antarmuka

\begin{tabular}{ccccc}
\hline $\begin{array}{c}\text { Kepuasan Pengguna } \\
\text { terhadap rancangan } \\
\text { antarmuka M-Desa }\end{array}$ & $\begin{array}{c}\text { jumlah } \\
\text { responden } \\
(\mathrm{x})\end{array}$ & $\begin{array}{c}\text { nilai } \\
(\mathrm{y})\end{array}$ & $\mathrm{xy}$ & $\begin{array}{c}\%= \\
(\mathrm{xy} / \mathrm{z})\end{array}$ \\
\hline $\begin{array}{c}\text { Sangat Tidak Setuju (STS) } \\
\text { Tidak Setuju (TS) }\end{array}$ & 1 & 1 & 1 & 0.2 \\
Ragu-ragu (R) & 18 & 2 & 6 & 1.2 \\
Setuju (S) & 45 & 4 & 54 & 10.6 \\
Sangat Setuju (S) & 54 & 5 & 270 & 52.8 \\
z & & & 511 & \\
\hline
\end{tabular}

Melihat dari hasil uji rancangan antarmuka dan kuesioner kepada warga dan petugas Desa maka diperoleh hasil bahwa hampir $98.6 \%$ puas terhadap sistem M-Desa ini untuk dapat diimplementasikan.

\section{7) KESIMPULAN}

Sistem Informasi Pelayanan Administrasi Kependudukan Desa (M-DESA) dirancang untuk memberikan informasi tentang pendaftaran pembuatan E-KTP, KK, AKTE Kelahiran, Surat Pengantar Nikah, surat kehilangan, mengurus kepindahan dan surat kematian sehingga dapat membantu pihak kantor desa dalam pembuatan surat keterangan yang dibutuhkan oleh warga. Melalui Sistem Informasi Pelayanan Administrasi Kependudukan Desa (M-DESA) ini masyarakat dimudahkan dalam memperoleh informasi yang ada di Kantor Desa, yaitu rencana kegiatan yang akan yang dilaksanakan nantinya dan informasi persyaratan dalam membuat permohonan surat keterangan. Sistem Informasi Pelayanan Administrasi Kependudukan Desa (M-DESA) dirancang menggunakan metode User Centered Design (UCD) dengan menyebarkan kuesioner. Metode ini berfokus terhadap pengguna sistem atau user, sehingga rancangan sistem yang dibuat dapat disesuaikan dengan kebutuhan user (warga dan petugas desa) sebagai sasaran pengguna dari sistem Informasi Pelayanan Administrasi Kependudukan Desa (M-DESA).

\section{REFERENSI}

Amborowati, A. (2008). Rancangan Sistem Pameran Online menggunakan Metode UCD (User Centered Design). STMIK AMIKOM Yogyakarta, 1-15.

Anwar, S., \& Irawan, F. (2017). Pengadaan Suku Cadang Mobil Pada. Jurnal Pilar Nusa Mandiri, 13(1), $113-121$.

Ariansyah, \& Josi, A. (2017). Pengembangan Framework Yii Dalam Pembangunan Sistem Inventaris Stmik Prabumulih Dengan Konsep User Centered Design (UCD). Jurnal Informatika: Jurnal Pengembangan

http://ejournal.bsi.ac.id/ejurnal/index.php/ijse 
Indonesian Journal on Software Engineering (IJSE)

Vol. 7, No. 1, Juni 2021, hlm. 1-9

IT Poltek Tegal, 03(01), 26-30.

Brandenburg, L. (2017). How to Create an Entity Relationship Diagram (ERD). Https://Www.Bridging-theGap.Com.

Gani, A. G. (2018). Analisis Sistem Informasi Pengelolaan Data Alumni Berbasis Codeigniter PHP Framework. Jurnal Sistem Informasi Universitas Suryadarma, 5(2), 76-98.

GIS Geography.com. (2018). What is Geographic Information Systems (GIS)? GISGeography.Com.

Hakim, R. (2012). Pengantar Sistem Informasi Bisnis. Elex Media Komputindo.

Hindarto, H., Anshory, I., \& Efyanti, A. (2016). Aplikasi Pengukur Deteksi Detak dan Suara Jantung. Saintek, 13(1), 1-4.

Israel, B. T., \& Ph, D. (2010). Using Design Psychology to Create Ideal Places.

Kurniawati, L., Safitri, A., \& Akbar, D. D. (2019). User Centere Design (Ucd) Untuk Rancang Bangun Sistem Informasi Pengolahan Data Simpan Pinjam Pada Koperasi. Jurnal Ilmu Pengetahuan Dan Teknologi Komputer, 4(1), 1-8. http://ejournal.nusamandiri.ac.id/ejurnal/index.php/jitk/article/view/839/491

L. Albani and G. Lombardi (FIMI). (2010). User Centred Design for EASYREACH. November 2010, 1-45.

Maryani, Y. M. K. dan I. (2017). Sistem Informasi Akademik Berbasis WEB. 5(2), 82-89.

Muhammad, B., \& Bahar, A. (2016). Model Aplikasi Sistem Pelayanan Terpadu Pada Kantor Kelurahan. Teknik Informatika, 5(1), 877-1021.

Pahlevi, O., Mulyani, A., \& Khoir, M. (2018). Sistem Informasi Inventori Barang Menggunakan Metode Object Oriented Di Pt. Livaza Teknologi Indonesia Jakarta. PROSISKO: Jurnal Pengembangan Riset Dan Observasi Sistem Komputer, 5(1), 27-35.

Visual-Paradigm. (2018). What is Entity Relationship Diagram (ERD)? Visual Paragidm. 